\title{
PENGARUH KESESUAIAN KOMPENSASI, MORALITAS MANAJEMEN, DAN KEEFEKTIFAN PENGENDALIAN INTERNAL TERHADAP KECENDERUNGAN KECURANGAN AKUNTANSI PADA PERUSAHAAN KONSTRUKSI DI MANADO
}

\author{
Shelby Defiany Alou ${ }^{1}$, Ventje Ilat ${ }^{2}$, Hendrik Gamaliel $^{3}$ \\ 1.2.3 Fakultas Ekonomi dan Bisnis, Jurusan Akuntansi, Universitas Sam Ratulangi, Jl. Kampus Bahu, Manado, \\ 95115, Indonesia \\ E-mail : shelbyalou@gmail.com
}

\begin{abstract}
Within the scope of accounting, the concept of fraud is a deviation from accounting procedures that should not be applied in an entity. Such delusions will have an impact on the financial statements presented by the company (Ariani, 2014). This study aims to examine the effect of conformity of compensation, management morality, and effectiveness of internal controls on the tendency of accounting fraud in employees of construction companies in Manado. The population in this study is a construction company in Manado. Sampling was done by purposive sampling which amounted to 4 companies. The sample of this research is 36 employees who work in the finance department at construction companies in Manado. The method of data analysis used is multiple linear regression analysis. The result of this research are: (1) compensation suitability has no effect on the tendency of accounting cheating on employees of construction companies in Manado; (2) management morality has no effect on the tendency of accounting fraud in employees of construction companies in Manado; (3) the effectiveness of internal controls has a positive and significant effect on the tendency of accounting cheating on construction company employees in Manado.

Keywords: Compensation Compliance, Management Morality, Effectiveness of Internal Control, Accounting Fraud Trend
\end{abstract}

\section{PENDAHULUAN}

\subsection{Latar Belakang}

Kecenderungan kecurangan akuntansi telah menarik banyak perhatian media dan menjadi isu yang menonjol serta penting di mata pemain bisnis dunia. Dalam lingkup akuntansi, konsep kecurangan atau fraud merupakan penyimpangan dari prosedur akuntansi yang seharusnya tidak diterapkan dalam suatu entitas. Kecenderungan kecurangan akuntansi merupakan kesengajaan untuk melakukan tindakan penghilangan atau penambahan jumlah tertentu sehingga terjadi salah saji dalam laporan keuangan (Nelson, 2012). Namun, kesempatan untuk melalukan kecurangan tergantung pada kedudukan pelaku terhadap objek kecurangan. Biasanya, pihak manajer melakukan kecurangan untuk kepentingan perusahaan, Salah saji yang berasal dari penyalahgunaan aktiva meliputi penggelapan aktiva perusahaan yang mengakibatkan laporan keuangan tidak disajikan sesuai dengan prinsip-prinsip akuntansi yang berlaku umum.

Manajer (agent) diberikan kewenangan oleh principal dalam mengelola perusahaan oleh sebab itu manajer memiliki pengetahuan yang lebih mendalam terkait kondisi perusahaan dibandingkan dengan pemegang saham, hal tersebut mengakibatkan berbagai konsekuensi seperti asymetry information. Asimetris informasi yang terjadi dikarenakan adanya praktik manajemen laba dapat menimbulkan informasi yang salah dan tidak mencerminkan kondisi yang sebenarnya sehingga menyesatkan para pengguna laporan. Laba yang disajikan menjadi diragukan kualitasnya (Rachmasari, 2015: 2). Perusahaan yang melakukan perataan laba ataupun yang tidak melakukan perataan laba bisa dideteksi melalui 
indeks Eckel dengan melihat apabila nilai indeks Eckel $>1$ maka perusahaan tidak melakukan perataan laba, tetapi apabila indeks Eckel $<1$, maka perusahaan tersebut melakukan perataan laba.

Dalam penelitian ini peneliti mengambil empat perusahaan konstruksi sebagai objek penelitian yaitu CV. Fanondiozan Indah Lestari, CV. Nimanga, CV. Esaketer, dan CV. Fapon Putra Perkasa. Berdasarkan hasil dari nilai indeks Eckel pada indeks perataan laba CV. Fanondiozan Indah Lestari, CV. Nimanga, CV. Esaketer, dan CV. Fapon Putra Perkasa yaitu 1, mengindikasikan perusahaan melakukan kebijakan-kebijakan pengaturan laba yang sering kali muncul kecurangan baik dilakukan oleh perusahaan untuk menghindari laba ataupun individu / karyawan.

Menurut penelitian dari Bartenputra (2016) ada beberapa faktor yang menyebabkan kecurangan masih terjadi. Antara lain yaitu kesesuaian kompensasi. Kompensasi adalah semua pendapatan yang berbentuk uang, barang langsung ataupun tidak langsung yang diterima oleh karyawan sebagai imbalan atas yang diberikan kepada perusahaan (Hasibuan, 2013: 117). Faktor lain penyebab maraknya tindak kecurangan akuntansi masih terjadi menurut Kusumastuti (2012) adalah moralitas manajemen. Perusahaan memiliki tanggung jawab moral dan sosial yang pada tingkat operasional, tanggung jawab moral ini diwakili oleh manajemen. Selain faktor-faktor yang telah diuraikan sebelumnya menurut Peterson (2015) keefektifan pengendalian internal juga merupakan salah satu faktor yang dapat menyebabkan tindak kecenderungan kecurangan akuntansi.

\subsection{Tujuan Penelitian}

Tujuan penelitian yang ingin dicapai dalam penelitian ini adalah sebagai berikut :

1. Meperoleh bukti empiris keterkaitan bersama antara Kesesuaian Kompensasi, Moralitas Manajmen, dan Keefektifan Pengendalian Internal Terhadap Kecenderungan Kecurangan Akuntansi.

2. Memperoleh bukti empiris keterkaitan antara Kesesuaian Kompensasi dengan Kecenderungan Kecurangan Akuntansi.

3. Memperoleh bukti empiris keterkaitan antara Moralitas Manajemen dengan Kecenderungan Kecurangan Akuntansi.

4. Memperoleh bukti empiris keterkaitan antara Keefektifan pengendalian Internal dengan Kecenderungan Kecurangan Akuntansi.

\section{TINJAUAN PUSTAKA}

\subsection{Teori Keagenan}

Teori keagenan merupakan suatu kontrak antara prinsipal dengan agen. Hubungan keagenan dapat menimbulkan masalah pada saat pihak - pihak yang bersangkutan mempunyai tujuan yang berbeda, pemilik modal menghendaki bertambahnya kekayaan dan kemakmuran para pemilik modal, sedangkan manajer juga menginginkan bertambahnya kesejahteraan bagi para manajer. Dengan demikian muncullah konflik kepentingan antara pemilik (investor) dengan manajer (agen) (Jusriani, 2013).

\subsection{Kecurangan Akuntansi}

Menurut Karyono (2013: 4-5) fraud diistilahkan sebagai kecurangan yang mengandung makna suatu penyimpangan dan perbuatan melanggar hukum (illegal act), yang dilakukan dengan sengaja untuk tujuan tertentu misalnya menipu atau memberikan gambaran keliru (mislead) kepada pihak-pihak lain, yang dilakukan oleh orang-orang baik dari dalam maupun dari luar organisasi. Menurut teori GONE terdapat empat faktor pendorong seorang melakukan kecurangan, yaitu: greed (keserakahan), opportunity (kesempatan), need (kebutuhan) dan exposure (pengungkapan) (Herman, 2013). 


\subsection{Kesesuaian Kompensasi}

Kadarisman (2012: 1) kompensasi adalah apa yang seorang karyawan/pegawai/pekerja terima sebagai balasan dari pekerjaan yang diberikannya baik upah perjam ataupun gaji periodik yang didesain dan dikelola oleh bagian personalia.

\subsection{Moralitas Manajemen}

Moral adalah perbuatan, sikap ataupun tingkah laku yang dilakukan oleh manusia dalam kehidupan sehari-hari sangatlah erat kaitannya dengan orang lain. Secara umum moralitas adalah hal mendasar dalam penilaian atas setiap tindakan yang diambil oleh manusia. Moralitas berkaitan dengan orang lain bukan hanya mengenai kepentingan pribadi. Serta moralitas merupakan pemikiran yang objektif dan rasional. Selain itu moralitas merupakan hukum yang universal yang penting (Kusumastuti, 2012).

\subsection{Keefektifan Pengendalian Internal}

Hery (2013: 159) mengemukakan pengertian pengendalian intern adalah seperangkat kebijakan dan prosedur untuk melindungi aset atau kekayaan perusahaan dari segala bentuk tindakan penyalahgunaan, menjamin tersedianya informasi akuntansi perusahaan yang akurat, serta memastikan bahwa semua ketentuan (peraturan) hukum/undang-undang serta kebijakan manajemen telah dipatuhi atau dijalankan sebagaimana mestinya oleh seluruh karyawan perusahaan.

\subsection{Hipotesis}

H1= Kesesuaian Kompensasi, Moralitas Manajemen, dan Keefektifan Pengendalian Internal berpengaruh terhadap Kecenderungan Kecurangan Akuntansi

$\mathrm{H} 2=$ Kesesuaian Kompensasi berpengaruh terhadap Kecenderungan Kecurangan Akuntansi

H3= Moralitas Manajemen berpengaruh terhadap Kecenderungan Kecurangan Akuntansi

H4= Keefektifan Pengendalian Internal berpengaruh terhadap Kecenderungan Kecurangan Akuntansi

\subsection{Penelitian Terdahulu}

1. Penelitian yang dilakukan oleh Adelin (2013), menunjukkan efektivitas pengendalian internal dan ketaatan pada aturan akuntansi berpengaruh negatif terhadap KKA sedangkan perilaku tidak etis berpengaruh positif terhadap KKA.

2. Penelitian yang dilakukan oleh Aranta (2013), menunjukkan bahwa moralitas aparat berpengaruh negatif terhadap kecenderungan kecurangan akuntansi, sedangkan asimetri informasi berpengaruh positif terhadap kecenderungan kecurangan akuntansi.

3. Penelitian yang dilakukan oleh Thoyibutan (2012), menunjukkan bahwa kesesuaian SPI dan sistem kompensasi berpengaruh negatif terhadap KKA, sedangkan perilaku tidak etis berpengaruh positif terhadap KKA.

\section{METODE PENELITIAN}

\subsection{Jenis Penelitian}

Jenis penelitian ini adalah metode deskriptif. Metode deskriptif merupakan suatu penelitian yang bertujuan untuk menggambarkan keadaan objek yang diteliti berdasarkan fakta-fakta yang ada dengan cara mengumpulkan, mengolah, dan menganalisisberbagai masam data sehingga dapat ditarik suatu kesimpulan. Dalam penelitian ini bertujuan untuk mengetahui Pengaruh Kesesuaian Kompensasi, Moralitas manajemen, dan Keefektifan Pengendalian Internal Terhadap Kecenderungan Kecurangan Akuntansi Pada Perusahaan Konstruksi Di Manado. 


\subsection{Tempat dan Waktu Penelitian}

Penelitian ini akan dilakukan pada CV. Fapon Putra Perkasa (Jl. Ranotana Weru Lingk 4 Manado), CV. Fanondiozan Indah Lestari (Jl. Air Terang Malalayang), CV. Nimanga (Wanea Lingkungan 2 No. 52 Manado), dan CV. Esaketer (Bumi Beringin Lingk III Kec. Wenang Manado). Penelitian ini dilakukan pada bulan Maret 2017.

\subsection{Populasi dan Sampel}

Populasi yang dipilih dalam penelitian ini adalah seluruh karyawan perusahaan konstruksi pada CV. Fapon Putra Perkasa, CV. Fanondiozan Indah Lestari, CV. Nimanga, dan CV. Esaketer. Teknik pengambilan sampel dalam penelitian ini berupa purposive sampling, dimana hanya seseorang atau sesuatu hal yang diambil sebagai sampel. Adapun kriteria dalam penelitian ini difokuskan pada semua pihak yang menerima delegasi wewenang dan tanggung jawab untuk terlibat dalam penggunaan dana yang dianggarkan, pelaksana akuntansi, dan orang yang bertugas berkaitan dengan laporan keuangan dan laporan pertanggung jawaban.

\subsection{Jenis dan Sumber Data}

Penelitian ini menggunakan metode analisis data kuantitatif yaitu menggunakan rumus - rumus statisktik yang disesuaikan judul penelitian dan rumusan masalah, untuk perhitungan angka-angka dalam rangka menganalisis data yang diperoleh dari perusahaan konstruksi di Manado. Sumber data yang digunakan dalam penelitan ini yaitu data primer yang diperoleh secara langsung melalui pembagian kuesioner pada perusahaan konstruksi di Manado.

\subsection{Teknik Pengumpulan Data}

Teknik pengumpulan data yang dilakukan adalah dengan menggunakan metode kuesioner. Metode kuesioner adalah metode pengumpulan data dengan cara menggunakan daftar pertanyaan yang diajukan kepada responden untuk dijawab dengan memberikan angket. Dalam hal ini peneliti melakukan pembagian kuesioner untuk perusahaan konstruksi yang ada di Manado.

\subsection{Definisi dan Pengukuran Variabel Operasional}

$\mathrm{Y}=$ Kecenderungan Kecurangan Akuntansi, variabel ini diukur dengan skala likert.

$\mathrm{X}_{1} \quad=$ Kesesuaian Kompensasi, variabel ini diukur dengan skala likert.

$\mathrm{X}_{2} \quad=$ Moralitas Manajemen, variabel ini diukur dengan skala likert.

$\mathrm{X}_{3}=$ Keefektifan Pengendalian Internal, variabel ini diukur dengan skala likert.

\subsection{Metode Analisis}

Metode yang digunakan untuk menganalisis data instrumen penelitian berupa kuesioner adalah uji kualitas data dengan melakukan uji validitas dan uji reabilitas. Selanjutnya agar hasil perhitungan dapat diinterprestasikan dengan akurat dilakukan uji asumsi klasik yang meliputi uji normalitas, uji multikolonieritas dan uji heteroskedastisitas. Terakhir, dilakukan pengujian terhadap model regresi linear berganda yang meliputi uji koefisien determinasi $\left(\mathrm{R}^{2}\right.$ ), uji signifikan simultan (uji $\mathrm{F}$ ), dan uji signifikan parameter individual (uji t). Semua uji analisis ini dilakukan dengan bantuan software SPSS Statistic versi 22. 


\section{HASIL PENELITIAN DAN PEMBAHASAN \\ 4.1. Gambaran Umum Objek Penelitian \\ Profil Perusahaan CV. Fapon Putra Perkasa}

CV. Fapon Putra Perkasa merupakan perusahaan kontraktor yang bergerak di bidang konstruksi bangunan. Usaha kontraktor ini didirikan oleh Bpk Farth Pontonuwu sekaligus sebagai pemilik usaha. Beliau dibantu oleh teman dan saudaranya untuk membangun usaha kontraktor ini.

\section{Profil Perusahaan CV. Fanondiozan Indah Lestari}

CV. Fanondiozan Indah Lestari didirikan oleh sepasang suami istri yang sudah berpengalaman dalam bidang kontraktor dan memiliki tekad untuk maju dan terus berkembang dalam dunia usaha konstruksi dengan melihat perkembangan ekonomi, pembangunan dan meningkatnya dunia teknologi khususnya Sulawesi Utara yang sangat memungkinkan untuk berkembang.

\section{Profil Perusahaan CV. Nimanga}

CV. Nimanga merupakan perusahaan swasta yang bergerak di bidang kontraktor. CV. Nimanga didirikan pada 24 Januari 2002.

\section{Profil Perusahaan CV. Esaketer}

CV. Esaketer adalah perusahaan yang bergerak di bidang General Suplier dan Kontraktor yang melayani perusahaan menengah dan perusahaan besar, baik swasta dan pemerintahan.

\subsection{Hasil Penelitian}

Dalam penelitian ini responden yang digunakan adalah para karyawan yang menerima delegasi wewenang dan tanggung jawab untuk terlibat dalam penggunaan dana yang dianggarkan, pelaksana akuntansi, dan orang yang bertugas berkaitan dengan laporan keuangan dan laporan pertanggung jawaban pada CV. Fapon Putra Perkasa, CV. Fanondiozan Indah Lestari, CV. Nimanga, dan CV. Esaketer.

Penyebaran kuesioner dilakukan pada tanggal 20 Maret 2017 sampai dengan tanggal 27 Maret 2017. Dari jumlah 40 kuesioner yang dibagikan, jumlah kuesioner yang dikembalikan adalah sebanyak 36 .

\section{Uji Kualitas Data}

Untuk melihat apakah data yang diperoleh dari kuesioner yang dibagikan dapat dipercaya dilakukan uji validitas dan uji reliabilitas. Penelitian ini telah lulus uji validitas dan uji reliabilitas.

\section{Uji Asumsi Klasik}

Agar hasil penelitian dapat diinterprestasikan dengan akurat maka dilakukan uji asumsi klasik. Penelitian ini telah lulus uji normalitas, multikolinieritas serta heterokedastisitas.

\section{Uji Hipotesis}

Uji Koefisien Determinasi $\left(\mathbf{R}^{2}\right)$ Model Summary

\begin{tabular}{|l|l|l|l|l|}
\hline Model & $\mathrm{R}$ & R Square & Adjusted R Square & $\begin{array}{l}\text { Std. Error of the } \\
\text { Estimate }\end{array}$ \\
\hline 1 & $.629^{\mathrm{a}}$ & .396 & .339 & 3.174 \\
\hline
\end{tabular}

a. Predictors: (Constant), Keefektifan Pengendalian Internal, Moralitas Manajemen, Kesesuaian Kompensasi

Sumber: Data Primer yang Diolah (2017) 
Dari hasil uji statistik uji regresi linear berganda, nilai adjusted $R^{2}$ adalah sebesar 0,339 . Hal ini berarti kemampuan variabel independen dalam menjelaskan variabel dependen adalah sebesar 33,9\% sedangkan $66,1 \%$ dijelaskan oleh variabel lain yang tidak diteliti dalam penelitian ini.

\section{Uji Signifikan Simultan (Uji F)}

\begin{tabular}{|ll|l|l|l|l|l|}
\hline \multicolumn{7}{|c|}{ ANOVA $^{\mathbf{a}}$} \\
\hline 1 & & Sum of Squares & Df & Mean Square & F & Sig. \\
& Regression & 211.263 & 3 & 70.421 & 6.990 & $.001^{\text {b }}$ \\
& Residual & 322.376 & 32 & 10.074 & & \\
& Total & 533.639 & 35 & & & \\
\hline
\end{tabular}

a. Dependent Variable: Kecenderungan Kecurangan Akuntansi

b. Predictors: (Constant), Keefektifan Pengendalian Internal, Moralitas Manajemen, Kesesuaian Kompensasi

Sumber: Data Primer yang Diolah (2017)

H1= Kesesuaian Kompensasi, Moralitas Manajemen, dan Keefektifan Pengendalian Internal berpengaruh terhadap Kecenderungan Kecurangan Akuntansi

Hasil perbandingan antara $\mathrm{F}$ hitung diperoleh sebesar 6,990 dengan tingkat signifikan 0,001 . Sedangkan pada $\mathrm{F}$ tabel sebesar 2,92. Hasil perbandingan antara $\mathrm{F}$ hitung dan $\mathrm{F}$ tabel yaitu $\mathrm{F}$ hitung $=6,990>\mathrm{F}$ tabel $=2,92$ dengan tingkat signifikan $0,001<0,05$. Maka dapat disimpulkan bahwa seluruh variabel independen yaitu Moralitas Manajemen, Kesesuaian Kompensasi, dan Keefektifan Pengendalian Internal secara bersama-sama mempengaruhi variabel dependen Kecenderungan Kecurangan Akuntansi secara positif. Maka hipotesis H1 diterima.

Uji Signifikan Parameter Individual (Uji t)

\section{Coefficients $^{\mathrm{a}}$}

\begin{tabular}{|c|c|c|c|c|c|}
\hline \multirow[b]{2}{*}{ Model } & \multicolumn{2}{|c|}{$\begin{array}{l}\text { Unstandardized } \\
\text { Coefficients }\end{array}$} & \multirow{2}{*}{$\begin{array}{l}\text { Standardized } \\
\text { Coefficients } \\
\text { Beta } \\
\end{array}$} & \multirow[b]{2}{*}{$\mathrm{T}$} & \multirow[b]{2}{*}{ Sig. } \\
\hline & $\mathrm{B}$ & Std. Error & & & \\
\hline 1 (Constant) & 17.520 & 7.422 & & 2.361 & .024 \\
\hline Kesesuaian Kompensasi & -.105 & .218 & -.085 & -.482 & .633 \\
\hline Moralitas Manajemen & .212 & .247 & .134 & .858 & .397 \\
\hline $\begin{array}{l}\text { Keefektifan Pengendalian } \\
\text { Internal }\end{array}$ & .488 & .157 & .604 & 3.105 & .004 \\
\hline
\end{tabular}

a. Dependent Variable: Kecenderungan Kecurangan Akuntansi

Sumber: Data Primer yang Diolah (2017).

\section{H2= Kesesuaian Kompensasi berpengaruh terhadap Kecenderungan Kecurangan Akuntansi \\ Variabel Kesesuaian Kompensasi menunjukkan nilai t hitung sebesar 0,482 (dari sisi} kiri) lebih kecil dari nilai t tabel yakni sebesar 2,037. Selain itu, nilai signifikan sebesar 0,633 yang mana lebih besar dari 0,05 . Hal ini menunjukkan bahwa secara parsial kesesuaian kompensasi tidak memiliki pengaruh terhadap Kecenderungan Kecurangan Akuntansi. Maka hipotesis $\mathbf{H} 2$ ditolak.

H3= Moralitas Manajemen berpengaruh terhadap Kecenderungan Kecurangan Akuntansi 
Variabel Moralitas Manajemen menunjukkan nilai t hitung sebesar 0,858 lebih kecil dari $\mathrm{t}$ tabel yakni 2,037. Selain itu, nilai signifikan sebesar 0,397 yang mana lebih besar dari 0,05. Hal ini menunjukkan bahwa secara parsial moralitas manajemen tidak memiliki pengaruh terhadap Kecenderungan Kecurangan Akuntansi. Maka hipotesis H3 ditolak.

\section{H4= Keefektifan Pengendalian Internal berpengaruh terhadap Kecenderungan Kecurangan Akuntansi \\ Variabel Keefektifan Pengendalian Internal menunjukkan nilai t hitung sebesar 3,105} lebih besar dari t tabel yakni 2,037. Selain itu, nilai signifikan sebesar 0,004 lebih kecil dari 0,05. Hal ini menunjukkan bahwa secara parsial keefektifan pengendalian internal berpengaruh signifikan terhadap Kecenderungan Kecurangan Akuntansi. Maka hipotesis H4 ditolak.

Berdasarkan tabel persamaan regresi linear berganda dapat ditulis sebagai berikut:

$$
\mathrm{Y}=\mathbf{1 7 , 5 2 0}-\mathbf{0 , 1 0 5}+\mathbf{0 , 8 5 8}+\mathbf{3 , 1 0 5}+\mathrm{e}
$$

\begin{tabular}{|c|c|}
\hline \multicolumn{2}{|l|}{ Dimana: } \\
\hline Y & $=$ Kecenderungan Kecurangan Akuntansi \\
\hline$\alpha$ & $=$ Konstanta \\
\hline $\mathrm{X} 1$ & $=$ Kesesuaian Kompensasu \\
\hline $\mathrm{X} 2$ & $=$ Moralitas Manajemen \\
\hline X3 & $=$ Keefektifan Pengendalian Internal \\
\hline$\beta 1 \beta 2 \beta 3$ & $=$ Koefisien regresi \\
\hline & $=$ Standar error \\
\hline
\end{tabular}

\subsection{Pembahasan}

Pengaruh Kesesuaian Kompensasi, Moralitas Manajemen, dan Keefektifan Pengendalian Internal Terhadap Kecenderungan Kecurangan Akuntansi.

Berdasarkan uji simultan yang di dapat menunjukkan bahwa Kesesuaian Kompensasi (X1), Moralitas Manajemen (X2), dan Keefektifan Pengendalian Internal (X3) secara bersama-sama mempunyai pengaruh terhadap Kecenderungan Kecurangan Akuntansi (Y) dengan nilai $\mathrm{F}$ hitung dan $\mathrm{F}$ tabel yaitu $\mathrm{F}$ hitung $=6,990>\mathrm{F}$ tabel $=2,92$ dengan tingkat signifikan 0,001 <0,05. Hasil penelitian ini mendukung hasil penelitian dari Kusumastuti (2012) yang menyatakan bahwa Kesesuaian Kompensasi, Moralitas Manajemen, dan Keefektifan Pengendalian Internal secara bersama-sama berpengaruh terhadap Kecenderungan Kecurangan Akuntansi. Dalam penelitian ini menunjukkan bahwa kesesuaian kompensasi, moralitas manajemen, dan keefektifan pengendalian internal berpengaruh terhadap kecenderungan kecurangan akuntansi. Hal ini berarti semakin tingginya kesesuian kompensasi, moralitas manajemen, dan keefektifan pengendalian internal dapat menyebabkan kecenderungan kecurangan akuntansi dalam perusahaan.

\section{Pengaruh Kesesuaian Kompensasi terhadap Kecenderungan Kecurangan Akuntansi.}

Kesesuaian Kompensasi tidak memiliki pengaruh terhadap Kecenderungan Kecurangan Akuntansi. Hasil penelitian ini mendukung hasil penelitian sebelumnya yang dilakukan oleh Kusumastuti (2012) yang dalam penelitiannya menyatakan bahwa tidak ada pengaruh signifikan dari kesesuaian kompensasi terhadap kecenderungan kecurangan akuntansi. Sistem kompensasi yang sesuai diharapkan dapat membuat individu merasa tercukupi sehingga individu tidak melakukan tindakan yang merugikan organisasi termasuk melakukan kecurangan akuntansi. Kompensasi yang sesuai diharapkan mampu mengurangi adanya keinginan untuk melakukan tindakan curang (Kusumastuti, 2012). 


\section{Pengaruh Moralitas Manajemen terhadap Kecenderungan Kecurangan Akuntansi.}

Moralitas Manajemen tidak memiliki pengaruh terhadap Kecenderungan Kecurangan Akuntansi. Hasil penelitian ini mendukung hasil penelitian sebelumnya yang dilakukan oleh Rahmawati (2012) dan Kusumastuti (2012) yang dalam penelitiannya menyatakan bahwa tidak ada pengaruh dari moralitas manajemen terhadap kecenderungan kecurangan akuntansi. Hasil penelitian Kusumastuti (2012) menunjukan bahwa dengan meningkatkan moralitas manajemen dapat menurunkan kecenderungan kecurangan akuntansi. Penelitian ini juga berpendapat moralitas manajemen mempengaruhi kecenderungan kecurangan akuntansi. Artinya, semakin tinggi tahapan moralitas manajemen (tahapan pasca-konvensional), semakin manajemen memperhatikan kepentingan yang lebih luas dan universal dari pada kepentingan perusahaan semata, terlebih kepentingan pribadinya. Oleh karenanya, semakin tinggi moralitas manajemen, semakin manajemen berusaha menghindarkan diri dari kecenderungan kecurangan akuntansi.

\section{Pengaruh Keefektifan Pengendalian Internal terhadap Kecenderungan Kecurangan Akuntansi.}

Keefektifan pengendalian internal berpengaruh terhadap kecenderungan kecurangan akuntansi. Hasil penelitian ini didukung oleh hasil penelitian sebelumnya yang dilakukan oleh Giarini (2015), dan Meliany (2013) bahwa keefektifan pengendalian internal berpengaruh terhadap kecenderungan kecurangan akuntansi. Hal ini menunjukkan bahwa dalam keefektifan pengendalian internal maka pemeriksaan fisik atas kelayakan perusahaan (kas, persediaan, dan lain-lain) tidak dilakukan secara terus menerus sehingga dapat menimbulkan terjadinya kecenderungan kecurangan akuntansi (Meliany, 2013). Semakin rendah sistem pengendalian internal maka semakin tinggi terjadinya kecenderungan kecurangan akuntansi. Hal ini mengindikasikan jika pimpinan dan staf akuntansi dapat menerapkan sistem pengendalian internal yang efektif dalam perusahaan akan mencegah keenderungan kecurangan akuntansi (Zainal, 2013).

\section{PENUTUP}

\subsection{Kesimpulan}

Berdasarkan hasil analisis dan pembahasan mengenai pengaruh Kesesuaian Kompensasi, Moralitas Manajemen, dan Keefektifan Pengendalian Internal terhadap Kecenderungan Kecurangan Akuntansi pada Perusahaan Konstruksi yang ada di Manado, maka dapat ditarik kesimpulan sebagai berikut:

1. Kesesuaian Kompensasi, Moralitas Manajemen, dan Keefektifan Pengendalian Internal secara bersama-sama berpengaruh terhadap Kecenderungan Kecurangan Akuntansi. Hal ini dapat dibuktikan dari hasil perhitungan nilai $\mathrm{F}$ hitung dan $\mathrm{F}$ tabel yaitu $\mathrm{F}$ hitung $=6,990>\mathrm{F}$ tabel $=2,92$ dengan tingkat signifikan 0,001 lebih kecil dari 0,05 .

2. Kesesuaian Kompensasi tidak memiliki pengaruh terhadap Kecenderungan Kecurangan Akuntansi pada Perusahaan Konstruksi di Manado. Hal ini dapat dibuktikan dari hasil perhitungan nilai t sebesar -0,482 dan nilai signifikansi sebesar 0,633. Nilai signifikansi pengujian tersebut lebih besar dari 0,05 .

3. Moralitas Manajemen tidak memiliki pengaruh terhadap Kecenderungan Kecurangan Akuntansi pada Perusahaan Konstruksi di Manado. Hal ini dapat dibuktikan dari hasil perhitungan nilai $t$ sebesar 0,858 dan nilai signifikansi sebesar 0,397. Nilai signifikansi tersebut lebih besar dari 0,05.

4. Terdapat pengaruh positf dan signifikan antara Keefektifan Pengendalian Internal dengan Kecenderungan Kecurangan Akuntansi pada Perusahaan Konstruksi di Manado. Hal ini dapat dibuktikan dari hasil perhitungan diperoleh nilai t sebesar 3,105 dan nilai signifikansi sebesar 0,004. Nilai signifikansi pengujian tersebut lebih 
kecil dari 0,05 sehingga dapat dikatakan bahwa keefektifan pengendalian internal berpengaruh terhadap kecenderungan kecurangan akuntansi.

\subsection{Saran}

Dengan memperhatikan hasil analisis dan kesimpulan maka saran yang dapat diberikan adalah sebagai berikut:

1. Sebaiknya pimpinan perusahaan lebih meningkatkan pengendalian internal agar supaya dapat meminimalisir kecenderungan kecurangan akuntansi yang akan dilakukan oleh karyawan yang ada di perusahaan.

2. Untuk peneliti selanjutnya kiranya dapat memperbaiki keterbatasan yang ada dalam penelitian ini dan memperbanyak jumlah sampel agar supaya hasil yang akan didapat lebih akurat dari penelitian sebelumnya.

\section{DAFTAR PUSTAKA}

Adelin Vani. 2013. Pengaruh Pengendalian Internal, Ketaatan Aturan Akuntansi, Dan Perilaku Tidak Etis Terhadap Kecenderungan Kecurangan Akuntansi (Studi Empiris pada BUMN di Kota Padang. Jurnal Akuntansi. Vol. 1, No.3

Aranta Petra. 2013. Pengaruh Moralitas Aparat Dan Asimetri Informasi Terhadap Kecenderungan Kecurangan Akuntansi (Studi Empiris Pemerintah Kota Sawahlunto). Jurnal Akuntansi. Vol. 1, No.1

Ariani Ketut. 2014. Analisis Pengaruh Moralitas Individu, Asimetri Informasi Dan Keefektifan Pengendalian Internal Terhadap Kecenderungan Kecurangan Akuntansi Di PDAM Kabupaten Bangli. e-Journal S1 Ak Universitas Pendidikan Ganesha. Vol. 2, No. 1

Bartenputra Aryanda. 2016. Pengaruh Kesesuaian Kompensasi, Ketaatan Akuntansi Dan Asimetri Informasi Terhadap Kecenderungan Kecurangan Akuntansi (Studi empiris pada SKPD Kota Bukit tinggi). Jurnal Akuntansi. Vol. 4, No. 2

Giarini, Frisaha. 2015. Pengaruh Efektivitas Pengendalian Internal, Kesesuaian Kompensasi, dan Asimteri Informasi Terhadap Kecenderngan Kecurangan Akuntansi: Studi Empiris Pada Universitas Muhammadiyah Surakarta. Surakarta: Universitas Muhammadiyah Surakarta

Hasibuan, Malayu. 2013. Manajemen Sumber Daya Manusia. Cetakan Ketujuh Belas. Jakarta: Bumi Aksara

Herman Lisa. 2013. Pengaruh Keadilan Organisasi Dan Sistem Pengendalian Intern Terhadap Kecurangan (Studi Empiris Pada Kantor Cabang Utama Bank Pemerintah Di Kota Padang). Jurnal Akuntansi. Vol. 1, No. 1

Hery. 2013. Auditing (Pemeriksaan Akuntansi I). Cetakan Pertama. Jakarta: CAPS

Jusriani Fanindya. 2013. Analisis Pengaruh Profitabilitas, Kebijakan Deviden, Kebijakan Utang, Dan Kepemilikan Manajerial terhadap Nilai Perusahaan (Studi Empiris Pada Perusahaan Manufaktur Yang Terdaftar Di Bursa Efek Indonesia Periode 2009-2011. Diponegoro Journal of Accounting. Vol. 2, No. 2

Kadarisman, M. 2012. Manajemen Pengembangan Sumber Daya Manusia, Rajawali Pers, Jakarta

Karyono. 2013. Forensic Fraud, Edisi 1. Yogyakarta: ANDI

Kusumastuti Nur. 2012. Analisis Faktor-faktor Yang Berpengaruh Terhadap Kecenderungan Kecurangan Akuntansi Dengan Perilaku Tidak Etis Sebagai Bariabel Intervening. Diponegoro Journal of Accounting. Vol. 1 No. 1 
Meliany. 2013. Pengaruh Keefektifan Pengendalian Internal Dan Kesesuaian Kompensasi Terhadap Kecenderungan Kecurangan Akuntansi. Journal \& Proceeding FEB UNSOED. Vol. 3, No. 1

Nelson. 2012. Pre Fraud: An Empirical In Malaysia. International Journal of Economics and Finance Studies.Vol. 4, No. 1

Peterson Ozili. 2015. Forensic Accounting and Fraud. International Journal of Accounting and Economics Studies.Vol 3, No. 1

Rachmasari Putri. 2015. Analisis Pengaruh Faktor Risiko Kecurangan Terhadap Manajemen Laba (Studi Empiris pada Perusahaan Manufaktur yang Terdaftar pada Bursa Efek Indonesia Periode 2011-2013). Semarang: Universitas Diponegoro Semarang

Rahmawati Dina. 2012. Analisis Faktor-Faktor yang Berpengaruh Terhadap Praktik Peralatan Laba (Studi Pada Perusahaan Manufaktur yang Terdaftar di BEI Tahun 20072010). Jurnal Akuntansi. Vol. 1, No. 2

Thoyibatun Siti. 2012. Faktor - faktor Yang Berpengaruh Terhadap Perilaku Tidak Etis Dan Kecenderungan Kecurangan Akuntansi Serta Akibatnya Terhadap Kinerja Organisasi. Jurnal Ekonomi dan Keuangan. Vol. 16, No. 2

Zainal Rizki. 2013. Pengaruh Efektivitas Pengendalian Intern, Asimetri Informasi Dan Kesesuaian Kompensasi Terhadap Kecenderungan Kecurangan Akuntansi (Fraud) (StudiEmpiris Kantor Cabang Bank Pemerintah Dan Swasta Di Kota Padang). Jurnal Akuntansi. Vol. 1, No. 3 